
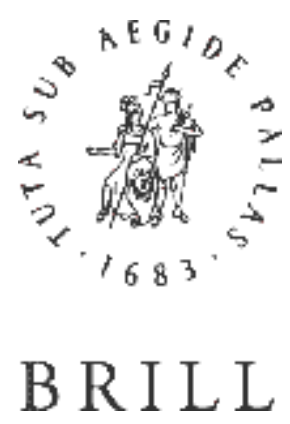

The Shared Meal-a Therapeutical Device: The Function and Meaning of Hos 6:6 in Matt 9:10-13

Author(s): Eric Ottenheijm

Source: Novum Testamentum, Vol. 53, Fasc. 1 (2011), pp. 1-21

Published by: Brill

Stable URL: https://www.jstor.org/stable/23056270

Accessed: 26-11-2019 09:16 UTC

\title{
REFERENCES
}

Linked references are available on JSTOR for this article: https://www.jstor.org/stable/23056270?seq=1\&cid=pdf-reference\#references_tab_contents You may need to log in to JSTOR to access the linked references.

JSTOR is a not-for-profit service that helps scholars, researchers, and students discover, use, and build upon a wide range of content in a trusted digital archive. We use information technology and tools to increase productivity and facilitate new forms of scholarship. For more information about JSTOR, please contact support@jstor.org.

Your use of the JSTOR archive indicates your acceptance of the Terms \& Conditions of Use, available at https://about.jstor.org/terms 


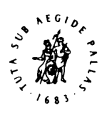

\title{
The Shared Meal—a Therapeutical Device
}

\section{The Function and Meaning of Hos 6:6 in Matt 9:10-13}

\author{
Eric Ottenheijm \\ Utrecht
}

\begin{abstract}
In Matt 9:10-13, the disciples of Jesus are asked why their master eats with tax-collectors and sinners. Both the question and the threefold answer are analysed in this study. Wisdom traditions prescribe Torah teachers not to engage with blatant sinners. This approach becomes contested in the first century C.E., as is clear from Pharisaic disputes on sinners and tax-collectors. In his answer, Jesus characterises himself as the divine doctor, who stirs the capacity to repentance by his sheer presence. The quote of Hosea functions as a legal justification of this strategy. Hos 6:6 points to the concept of good works, benevolent actions that save even blatant sinners.
\end{abstract}

\section{Keywords}

sinners; tax collectors; meals; doctor; good works; Torah teacher; Pharisees; repentance

In the Gospel of Matthew the Pharisees ask the disciples this question: "Why does your teacher eat with tax-collectors and sinners?" (Matt 9:11) ${ }^{1}$ Jesus hears this question and answers it in three steps:

(A) With a proverb: "Those who are well have no need of a physician, but those who are sick." (Matt 9:12)

(B) With a challenge: "Go and learn what this means," followed by a citation from Hos 6:6: "I desire mercy and not sacrifice." (Matt 9:13a)

(C) The summary: "For I came not to call the righteous, but sinners." (Matt 9:13b)

1) Unless indicated otherwise, translations are mine. 
Matthew differs from Mark 2:13-17 and Luke 5:27-32 primarily by the insertion of (B), the citation from Hos 6:6. ${ }^{2}$ This produces a three-part answer, the internal and logical coherency of which causes problems for exegetes. Moreover, some authoritative commentaries discern here a fundamental conflict between Jesus and the Jews. They point out the fact that Jesus' conception of the meal was the opposite of that of the Pharisees, who displayed a religiosity based on rules of purification, designed to exclude outsiders. Jesus' esteem for the physician would likewise differ from the traditional abhorrence of his alleged impurity. ${ }^{3}$

In this study we examine this dominant exegesis critically, and suggest an explanation which will clarify the logical coherence of Jesus' answer and relate it to the unity of the gospel. Our starting-point is a contextual analysis of the question posed by the Pharisees. From then onwards we elucidate the function and meaning of the Hosea citation (B), and the way in which Matthew interprets the apodictic sayings (A) and (C) using this citation. The traditio-historical connection with early Judaism is our guiding principle as regards method.

The study is constructed as follows: in section 1 we discuss the literary context and the genre-critical designation. Section 2 examines the background to the question posed by the Pharisees. Against this we analyse the three steps in the answer given by Jesus: the proverb about the doctor (section 3), the citation from Hos 6:6 (section 4) and the closing saying (section 5). The conclusions (section 6) round off the discussion.

\footnotetext{
2) U. Luz, Das Evangelium nach Mattbäus: Mt 8-17 (EKKNT l/2; 3. durchgesehene Auflage; Neukirchen-Vluyn: Benziger/Neukirchener, 1999) 44: "Es ist hier recht störend und sprengt den Kontext." For grammatical details see W.D. Davies and D.C. Allison, $A$ Critical and Exegetical Commentary according to Saint Matthew: Vol. II: Commentary on Matthew VIII-XVIII (ICC; Edinburgh: Clark, 1991) 103-107.

3) H. Frankemölle, Matthäus Kommentar I (Düsseldorf: Patmos, 1994) 315-317 characterises Jesus' behaviour as "Kontrastethik." Luz, Matthäus, 43-44 qualifies the episode as a sketch of the rift between the disciples of Jesus and the Jewish factions. Hosea 6:6 for the initiated reader criticizes the Pharisees with their "Reinheidstora, die Gemeinschaft mit Zöllnern und Sündern unmöglich machte." Davies, Commentary Vol. II, 102-103 feels that the dispute is a consequence of the provocative and prophetic performance of Jesus. Only C. Keener, A Commentary on the Gospel of Matthew (Grand Rapids: Eerdmans, 1999) 291 deviates from this pattern.
} 


\section{Literary Context and Genre}

The situation where Jesus is sitting at table with "many tax-collectors and sinners" (vs. 10) follows on from the earlier calling of Matthew (Levi in the parallel versions). ${ }^{4}$ Luke even lets Levi have the meal "in his house" (Luke 5:29; compare Mark 2:15). ${ }^{5}$ It is equally possible to read verses 10-13 in Matthew as an independent pericope. The genre-critical evaluation underlines this observation. The pericope is typified as a chreia, a literary form in which an anecdote concerning a wise man and a pithy saying by a wise man come together in a tradition. ${ }^{6}$ In addition it has also the unmistakable characteristics of a debate: an incident (vs. 10), a question (vs. 11) and an answer (vss. 12-13). Also the introduction to and the quotation from Hos 6:6 fit the character of a debate. The three-part answer that emerges in this way conforms to the early rabbinic preference for three-part sayings, as far as form is concerned and it also fits the Matthean structuring of the 'antitheses' in the Sermon on the Mount. ${ }^{7}$

\section{1. 'Sitz im Leben'}

According to most commentators this anecdote goes back to the historical fact that on occasion Jesus ate with tax-collectors and sinners and was subsequently questioned about it. ${ }^{8}$ It is plausible to assume that the pericope condenses historical situations to a case which was relevant to congregational practice. ${ }^{9}$

4) For the problem Levi/Mattheüs, see Luz, Matthäus, 40-43

5) See historical suggestions by Keener, Commentary, 296 and Luz, Matthäus, 41, note 5.

6) D.E. Smith, From Symposium to Eucharist: The Banquet in the Early Christian World (Minneapolis: Fortress Press, 2003) 228.

7) See W.D. Davies and D.C. Allison, A Critical and Exegetical Commentary according to Saint Matthew: Vol. I: Introduction and Commentary on Matthew I-VII (Edinburgh: Clark, 1988) 85-86, 95-96 and, for triadic structures in the Sermon on the Mount, G.H. Stassen, "The Fourteen Triads of the Sermon on the Mount (Matthew 5:21-7:12)", JBL 122/2 (2003) 267-308.

8) Keener, Commentary, 291. Smith's opinion, Symposium to Eucharist, 229 that this would concern "literary idealization" which serves "to symbolise redemption and calling to discipleship" is unsatisfactory.

9) Luz, Matthäus, 43 proposes a historical context of "Wanderradikalen," who repeatedly return home. The stylising of situations is also a tool used in the dispute about healing on the Sabbath, see my "Genezen als goed doen: Halachische logica in Mt 12:9-14," Bijdr $63 / 3$ (2002) 346 . 
The process of literary condensing certainly applies to the negative stereotyping of the Pharisees. In Matthew their function, certainly from chapter 12 onwards, is as flat characters, as hostile stereotypes, shallow opponents without dynamics. ${ }^{10}$ This stylising reflects the tension between the Matthean community and the surrounding groups led by disciples of the Pharisees. ${ }^{11}$

Nonetheless, historically it is conceivable that it was precisely these teachers who entered into debate with Jesus and tested his authority in public places. ${ }^{12}$ On the other hand, debate about the interpretation of the Law in no way implied hostility. Disputes about the Law and rival claims for authority are not unusual in the environment of the late Second Temple period. ${ }^{13}$

\section{The Incident: Jesus Takes a Meal with Tax-Collectors and Sinners}

The Pharisees see that Jesus eats with tax-collectors, and question the disciples about why he does this. Meals are religiously and socially important occasions, interchanges of social and religious intercourse, surrounded by rituals. ${ }^{14}$ Seeing that meals create fellowship and indicate fellowship, the choice of eating companions is a sensitive issue. What then is the premise for the Pharisees' question?

10) J. Kingsbury, Matthew as Story (2d ed.; Philadelphia: Fortress Press, 1988) 17-24.

11) A.J. Saldarini, Matthew's Christian-Jewish Community (Chicago/London: University of Chicago Press, 1994) 44-45; A. Overman, Matthew's Gospel and Formative Judaism: The Social World of the Matthean Community (Minneapolis: Fortress Press, 1990) 142. According to G.N. Stanton, A Gospel for a New People: Studies in Matthew (Edinburgh: T\&T Clark, 1992) 96-97, 155-157 Matthew's community has severed ties with Judaism.

12) Compare G. Theissen and A. Merz, Der historische Jesus: Ein Lehrbuch (2. durchgesehene Auflage; Göttingen: Vandenhoeck \& Ruprecht, 1997) 209. It is striking that our pericope attributes no hostile intentions, as is the case in Matt 12:14, but that these are read into the text. Note, however, Saldarini, Matthew's Community, 45: "Even if this is so, Matthew has not disguised the fact that many of the questions asked by the Pharisees and scribes are legitimate matters for discussion in first-century Judaism."

13) For debates in general, S. Safrai, "Halakha," in The Literature of the Sages First Part: Oral Tora, Halakha, Mishna, Tosefta, Talmud, External Tractates (ed. S. Safrai; CRINT 11/3a; Assen/Philadelphia: Fortress Press, 1987) 168-175; A.I. Baumgarten, The Flourishing of Jewish Sects in the Maccabean Era: An Interpretation (Leiden: Brill, 1997) 75-80.

14) See overview of types of meal in Smith, Symposium to Eucharist, 3. 


\subsection{Ritual Purification Regulations and Dietary Laws}

Frankemölle sets the scene in the context of a mixed community of Jews and non-Jews and the problem of table companions. ${ }^{15}$ Elsewhere in the gospel the attitude of Jesus to non-Jews is examined, but here this is not the case. ${ }^{16}$

An influential thesis detects a realistic outlook behind the question of the Pharisees. This distinguishes between those who support the purification regulations, the Pharisaic societies or associations, havurot, and those who do not, or not to the same extent, 'am ha'arets, literally the people of the land. The 'am ha'arets were people who did not keep strictly to the purification commandments nor the tithes. Participation in a meal with a Torah teacher would be reserved for those who upheld the laws of clean and unclean. Tax-collectors and sinners is therefore the designation of those who do not do that, or by their sinful behaviour make themselves ritually impure and therefore unfit to take part in the meal. The critical point of conflict then would be found in the criticism of these ritual dividing lines in society.

Did the Pharisaic emphasis on purification regulations imply that on the whole one did not eat with outsiders? Above all, did they see those who did not keep to this form of purification, or only did so to a lesser extent, as sinners? In the early traditions this certainly is not the case. ${ }^{17}$ Possibly there would have been Pharisees who looked down on others with disdain, as is the case with elite groups, but we have no indication that they viewed outsiders as sinners. ${ }^{18}$ Moreover, the havurah and the Pharisees were not identical. ${ }^{19}$ The havurah, the association, functioned as a club of the like-minded who took on themselves particular tasks and duties and carried out socio-religious tasks for the community. ${ }^{20} \mathrm{Up}$ until

\footnotetext{
15) Frankemölle, Matthäus, 317.

16) Matt 10:6,18; 15:21-28; 28:19. See also Luz, Matthäus, 43, note 30.

17) A. Oppenheimer, The Am Ha-Aretz: A Study in the Social History of the Jewish People in the Hellenistic-Roman Period (Leiden: Brill, 1977) 114.

18) Oppenheimer, 'Am Ha-Aretz, 179-184 shows, that hostile traditions concerning relations with the 'am ha'arets developed from the Yavnean era onwards and can be associated with (resistance to) the developing rabbinic culture of study after the fall of the Temple.

19) Oppenheimer, 'Am Ha-Aretz, 118-119, 131.

20) Oppenheimer, 'Am Ha-Aretz, 134, as correction to G. Alon, "The Bounds of the Laws of Levitical Uncleanness", in: Jews, Judaism and the Classical World: Studies in Jewish History in the Times of the Second Temple and Talmud (trans. I. Abrahams; Jerusalem: Magness
} 
the fall of the Temple they formed special, religious elite, not outside but within society. ${ }^{21}$ Insofar as our pericope reflects the truth about the Pharisees, a fully separatist ideology regarding meals does not seem to be appropriate. $^{22}$ Finally, the terminology which Matthew uses does not refer to ritual purity. Matthew brings this up in the debate about the washing of hands before eating (Matt 15:1-20). The conclusion is that ritual purity plays a role at most only by inference in the question of the Pharisees. ${ }^{23}$

\subsection{Meals with Tax-Collectors}

What sort of impression does it make when a teacher has a meal with tax-collectors and sinners? ${ }^{24}$ Matthew combines different nouns with taxcollectors: tax-collectors and prostitutes (Matt 21:31) and Gentiles and tax-collectors (Matt 18:17). The constant in this series is tax-collectors, and it would seem that, whatever the combination, we are dealing with a term of slander. ${ }^{25}$ We also encounter a similar phenomenon in rabbinic

Press, 1977) 211, especially note 61. See also J. Neusner, "The Fellowship in the Second Jewish Commonwealth", HTR 53 (1960) 125-142 and P. Peli, "The Havurot that were in Jerusalem", HUCA 55 (1984) 55-74.

21) The regulation of the zimmun, the call to say the blessing after the meal, was rooted in the meals of the havurah and presumes contact with outsiders and even with non-Jews: J. Heinemann, "Birkath Ha-Zimmun and Havura-Meals", JJS 13 (1962) 23-29.

22) That picture is of course completely different if we think of an Essene or Qumranite context, where outsiders were not admitted to the meal. According to Josephus (B.J. II. 8, $128)$ the Essenes admit to the midday meal "no-one who thinks differently" ( $\mu \eta \delta \varepsilon v i \mathrm{i} \epsilon \hat{v} v$ $\left.\dot{\varepsilon} \tau \varepsilon \rho \omega \delta \delta^{\prime} \xi \omega v\right)$. In the Qumran community the meal was only accessible to those who complied with the strict standards of purity of the community and who were not subject to punitive sanctions ( $1 Q S$ VI, 1-5; $1 Q S a$ II).

23) Cf. Keener, Commentary, 291. This differentiation would have been absent in Qumran, where certain moral sins could lead to ritual impurity, J. Klawans, Impurity and Sin in Ancient Judaism (Oxford: Oxford University Press, 2002) 75-85.

24) Keener, Commentary, 296. According to Davies, Commentary Vol. II, 101 the phrase "your teacher" implies a negative view of Jesus. However, R.H. Gundry, Matthew: A Commentary on his Literary and Theological Art (Michigan: Eerdmans, 1982) 167 remarks pointedly: "Your teacher' from the Pharisees makes a counterpart of 'their scribes' from Matthew (7:29). Though it is put in the mouths of the Pharisees the designation 'Teacher' enhances Jesus' authority."

25) Smith, Symposium to Eucharist, 235. See also F. Herrenbrück, Jesus und die Zöllner (WUNT 2/41; Tübingen: Mohr Siebeck, 1990) 229-230. Sinners are, so E.P. Sanders, Jesus and Judaism (London: SCM Press, 1985) 177: "the wicked... those who sinned willfully and heinously and who do not repent." Cf. Davies, Commentary Vol. II, 100-101; Keener, Commentary, 295. 
sources. ${ }^{26}$ This moral designation can however not be separated from the political context. Tax-collectors farmed taxes and toll rights as they collected various sorts of revenue or tolls in the service of the Roman occupying forces. ${ }^{27}$ Although the system of tax-farming was already in existence at the time of the Ptolemees, its prestige, certainly from the time of the rise of the Zealot resistance to the Roman census under Judas the Galilean cannot have been great. ${ }^{28}$

Tax-collectors were little loved. Firstly the regular taxation was a heavy burden on the local economy. ${ }^{29}$ Secondly exacting extra taxes involved corruption. Thirdly the emperor was depicted on the coins, with the result that handling this money placed one in a religiously suspicious position. This could have consequences for the status of purity of those involved. ${ }^{30}$

\subsection{Tax-Collectors and the Brotherhood of Pharisees}

Tax-collectors were people with whom it was better to avoid any social contact. ${ }^{31}$ Nonetheless they were part of society and belonged to the retainer class; they carried out administrative functions and served rulers or the wealthy. ${ }^{32}$ So one had then to relate to them or physically shut

26) I. Abrahams, Studies in Pharisaism and the Gospels (Cambridge: 1924; repr. New York: Ktav, 1967) 55.

27) The translation "tax-collectors" hides the fact that those spoken of here are not publicani, aristocratic Roman revenue gatherers, but tax farmers in a small way, local entrepreneurs who took out contracts to collect all sorts of taxes and tolls. The Romans worked in Palestine with publicani only for a short period. These only collected a few large revenues (tribute and land taxes). At the end of the first century B.C.E. this system also disappeared. The system of small tax farmers was used for the whole period; see Herrenbrück, Jesus und die Zöllner, 103, 107, 191-192, 225-226. Toll revenues are imaginable in Capernaum, where the transportation of goods took place; Davies, Commentary Vol. I, 558. Cf. also Theissen, Historische Jezus, 160 and see The Gospel of Matthew in Its Roman Imperial Context (eds. J. Riches and D. Sim; JSNTSS 276; London: T\&T Clark International, 2005) 65, 113.

28) Josephus, B.J. II.118, 433; cf. Sanders, Jesus and Judaism, 178.

29) According to Keener, Commentary, 292-293 these were about 30-40\%. Herrenbrück, Jesus und die Zöllner, 192 only speaks of the different types of taxes.

30) y. Hag 3:6, par. 1. In this tax-collectors share the ritual impurity of the heathen, in whose houses also one would prefer not to come (cf. Matt 8:8 and Luke 7:6).

31) t. Demai 2:17, but Herrenbrück, Jesus und die Zöllner, 201 suspects that behind this tradition there is an older connection between the haver and the mokhes.

32) A.J. Saldarini, Pharisees, Scribes and Sadducees: A Sociological Approach (Grand Rapids: Eerdmans, 1989) 37, 41-42; Riches, Imperial Context, 65. 
oneself off from society. ${ }^{33}$ The Pharisaic tradition also sought for a way of taking the tax-collector as a person without justifying his profession:

Initially they said (בראשונה היו אומרין): a companion (חבר) who has become a taxcollector (גבוי), ${ }^{34}$ is removed from his membership of the association (bavurah). ${ }^{35}$ They returned to this theme and said: as long as he is a tax-collector, he is untrustworthy; but should he give up his tax-collector's work, then he will be trustworthy again. (t. Demai 3:4, ed. Lieberman, 74; y. Demai 2:3 (23a) and b. Bek. 31a)

The phrase בראשונה היו אומריץ, "initially they said," refers to an old, generally stricter halakha which was later interpreted more liberally. ${ }^{36}$ This was also the case here; the text shows that an initial category difference was relaxed. Initially the job of receiver of taxes made him definitely unfit for membership of the havurah, even if he relinquished his job. ${ }^{37}$ But later they decided that it was the job alone which made him unfit. As soon as he turned his back on his profession, he could be regarded as trustworthy again, meaning fit for social and economic contact. ${ }^{38}$ This observation is doubly significant: on the one hand it confirms the impression, that the questioning by the Pharisees stems from surprise that Jesus should have a meal with tax-collectors who were active. It is even conceivable that what was expressed in their question was the old tradition in the halakha,

33) Some traditions even reflect a certain social standing: one tradition (y. Hag 2:2 (77d); y. Sanh. 6:9 (23c) tells about the son of the tax-collector Ma'ayan (בריה דמעין מוכס), for whom the whole province mourned at his death. See also the curious reference to the מע שה דבעיא מיכסא, "incident with the tax-collector Ba'aya" and the commentary of Rashi in b. Sanh. 44b. See the discussion in Herrenbrück, Jesus und die Zöllner, 215-216. The positive esteem of the גבאי by Rabbi (=R. Yehuda HaNasi, b. Sanh. 25b) is probably connected with his own economic status; Herrenbrück, Jesus und die Zöllner, 204.

34) In ms. Erfurt and editio princeps: גבאי, publicanus, according to Oppenheimer, Am Ha-Aretz, 142-143 and S. Lieberman, Tosephta Ki-fshutah: A Comprehensive Commentary on the Tosephta (Part I, New York: JTS, 1955) 224. Herrenbrück, Jesus und die Zöllner, 204 points out the passive נעשה, translated here as "has become," in order to conclude that there is coercion here. This is incorrect. The nip'al is an accepted way of rendering the result, see M.P. Fernandez, An Introductory Grammar of Rabbinic Hebrew (Leiden: Brill, 1999) 98-99 en 131. See for the meaning of גבאי as creditor m. 'Abot 3:17 (R. Akiva).

35) The baraita in b. Bek. 31a adds: "and if he has given it up they do not accept him".

36) Safrai, Literature of the Sages, 133-134.

37) According to the version in b. Bek. 31a.

38) Oppenheimer, Am Ha-Aretz, 155-156 limits this to socio-economic contacts. Cf. Klawans, Impurity and Sin, 109. The baraita in the Yerushalmi explains it however in this way, that he can again become a member of the brotherhood; see also b. Bek. 31 a. 
which categorically ruled out tax-collectors. On the other hand, Matthew's text testifies to the fact that this view became a topic of discussion in the first century C.E.

\subsection{What Does This Say about Jesus?}

Various traditions underline the truth that the wise man in his social relations should maintain a distance from evident sinners, as showed in the older halakha on tax collectors. ${ }^{39}$ Thus in a proverb from a teacher from the second century B.C.E., Nittai the Arbelite ${ }^{40}$ we read:

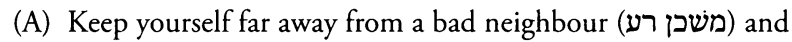

(B) and do not associate with the bad (ואל תתחבר לרשע) and

(C) and do not give up your belief in revenge. (m. 'Abot 1:7)

This proverb is divided into three sections just like the answer of Jesus. Its meaning, however, neatly matches the concerns of the Pharisees. The call not to associate yourself with bad people (B) can be understood in two ways. The first is that private dealings with bad people can lead you to imitate their behaviour. We encounter this logic as early as Sir 13:1: "Whoever touches pitch, gets dirty, and whoever associates with a haughty man, learns his ways" (וחבר אל לץ ילמד דרכו). ${ }^{41}$ The Greek recension

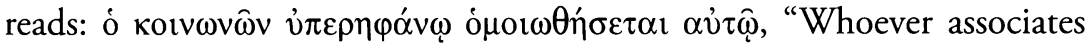
with a haughty man becomes like him." A second explanation is that associating with bad people gets you a bad name. R. Shimon ben Tsemah Duran (1361-1444) and R. Ovadiah Bertinoro (1450-1516) cite in their commentary on this proverb a parable borrowed from Talmudic sources: "It is like someone who goes into the house of a tanner. When he comes out again, will not the smell of the tannery hang about him?"42 Directed at the question of the Pharisees: if you eat with corrupt people, does the smell of corruption not hang about you, surely undesired by you? The

\footnotetext{
39) Ps $1: 1 ; 26: 5$.

40) According to some manuscripts Mattai. Arbel, or Irbid, is a little town near Tiberias.

41) According to ms. A, cited after P.C. Beentjes, The Book of Ben Sira in Hebrew: A Text Edition of All Extant Hebrew Manuscripts and a Synopsis of All Parallel Hebrew Ben Sira Texts (VTSup 58; Leiden: Brill, 1997).

42) Midr. Mishle 13; 'Abot R. Nat., b 11, ed. Schechter, 28; Pirqe R. El. 25:4 and Yal. Shimoni on Mishle, 940. It concerns part of a twin parable which offers comment on Prov 13:20. See also Abrahams, Studies, 57.
} 
Pharisees' question takes the leadership of Jesus seriously: why does this teacher eat with tax-collectors, whereas it is surely much better to eat with teachers? The latter was highly prized in the wisdom tradition (Sir 9:16) and it is a commandment and an honour to receive teachers into your house ( $m$. 'Abot 1:4).$^{43}$ In this light the reports about Pharisees who invite Jesus for a meal on the Sabbath (Luke 7:36, Luke 14) are no coincidence and a token of tribute to his position as a teacher.

\subsection{Strategy of Contact and Repentance}

In the saying of Sirach and according to the proverb of Nittai sin is an objective reality, demonstrable in the social sphere, something which one has to relate to. However this strategy too was under discussion. A discussion between the Houses of Hillel and Shammai (around 35-70 C.E.) ${ }^{44}$ offers a second clue about the changes in halakhic thinking in the Pharisaic world of the first century:

(For) Bet Shammai says: one may instruct a person only if he is wise and modest and is from a good background and rich.

And Bet Hillel says: one must instruct every man, for there were many sinners in Israel and they were brought into close contact with the study of the Torah and out of them came forth righteous, true and pure men. ('Abot R. Nat., a 3, ed. Schechter, $7 b-8 a)$

According to the House of Shammai only moral (חכם ועניו) and socioeconomically privileged men (ובן אבות ועשיר) are eligible to study the Torah, but according to the Hillelites there are no restrictions. Nevertheless Bet Hillel's motivation is interesting: even many people who are sinners can through Torah study be put onto the right path. That demands therefore an approach and openness on the part of the teacher. ${ }^{45}$ Bet Hillel

\footnotetext{
43) R. Shimon ben Tsemah Duran cites in his commentary Magen Aboth on m. 'Aboth 1:4 the first part of the twin parable: contact with the righteous is as if someone goes into the shop of the perfumer; even if he buys nothing, he is surrounded by a sweet fragrance! According to Der. Er. Zut. 6:1 a Torah teacher should not wear perfume in public.

44) For the Houses, their history and controversies, I. Ben Shalom, The School of Shammai and the Zealots' Struggle against Rome (PhD diss., Hebrew University, Jerusalem, 1993) (Hebr.), and my dissertation Disputen omwille van de Hemel: Rol en betekenis van intentie in de controverses over sjabbat en reinheid tussen de Huizen van Sjammai en Hillel (Amstelveen: Amphora, 2004) 41-112.

45) Hillel's patience toward disrespectful pupils indeed is legendary: $b$. $\breve{S} a b b .31$ a and parr.
} 
surprisingly enough is not concerned with the socio-economic status, only with the moral qualification: Torah study makes sinners into "righteous, true and pure men" (צדיקים חסידים וכשרים). Scholars question whether Bet Shammai focused exclusively on the aristocracy. The belief that material wealth should be a condition for studying the Torah seems to have been so problematical for the rabbinic tradition that commentators interpret the concept עשיר (rich) in a moral sense. ${ }^{46}$ Possibly the debate was originally exclusively about the moral qualifications of a pupil. The text would have been corrupted in transmission and originally read not עשיר, rich but כשר, suitable. ${ }^{47}$ This reading fits in with the answer of Bet Hillel, that out of people who were formally sinners pure men came forth (כשרים) and would also explain their silence on their socio-economic position. ${ }^{48}$ What is certain is that both Houses have differing opinions about the need for a morally principled character as a condition for being a pupil and that fact is relevant for the analysis of our pericope. In taking a meal with sinners, Jesus took the Hillel line of action: he did not avoid contact with sinners. The difference was that Jesus actively sought them out. This difference is gradual, for both Hillel and Jesus assume an essential attempt at reconciling the teacher with the sinner. ${ }^{49}$

We can make the intermediate conclusion that Jesus sat at table with sinners in order to induce them to change their ways. Jesus saw himself moreover as gifted with the power of God's way, by which he could stir people to change. To test this hypothesis in the subsequent part of this study the three elements of Jesus' reaction will be analysed.

\footnotetext{
46) Yosef ben Hayim Yavets (1533) comments: "He is rich who rejoices in his lot."

47) Ms. Epstein adds ובישט, and modest. The commentary Magen 'Abot adds: and suitable. See also Safrai, Literature of the Sages, 188.

48) However, Safrai's correction of the text raises the question of why כשר should be able to be read as עשיר. Did Bet Shammai have a preference for students who could devote themselves completely to Torah studies and who did not have to be absent for a profession? In the later rabbinic world this seems to have been a discussion point, cf. E.E. Urbach, The Sages: Their Concepts and Beliefs (trans. I. Abrahams; Jerusalem: Magness Press, 1977) 603-608, e.g. the discussion between R. Yohanan and Resh Laqish (fourth century C.E.) in $y . \breve{S} a b b .12: 3$ concerning rival parties in Sepphoris.

49) For Hillel's self-image, see D. Flusser, "Hillels' Self Awareness and Jesus," Judaism and the Origins of Christianity (Jerusalem: Magness Press, 1988) 509-514 and "Hillel and Jesus: Two Ways of Self-Awareness', in Hillel and Jesus: Comparative Studies of Two Major Religious Leaders (ed. J.H. Charlesworth; Minneapolis: Fortress Press, 1997) 86-87.
} 


\section{The Answer, Part (A): “Those Who Are Well Have No Need of a Physician, but Those Who Are Sick"}

This saying is a variant of a traditional proverb that presumes a connection between sin and sickness. ${ }^{50}$ In some texts the connection is chiefly of a metaphysical nature such as in Sir 21:3: "Every sin is like a double-

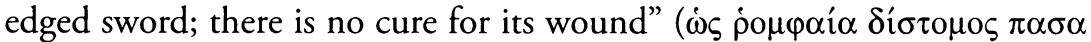

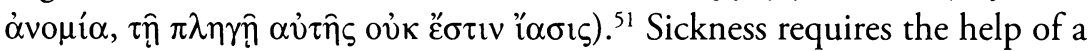
physician. Remarkably, the image of the doctor in early Judaism is not negative, contrary to that in the biblical period. Indeed, Sir 38:1-15 values the contribution of the doctor to the healing work of God and marks in this way a shift in the way human medical treatment is valued. ${ }^{52}$ This passage also contains some proverbial sayings that were in wide circulation. The phrase in Sir 38:1, רעי רופה לפני צרכו, "Make a friend of the doctor before you need him," has a negatively formulated variant in rabbinic sources: כבד את רופאך עד שלא תצטיריך לו, "Honour your doctor until you need him no more." ${ }^{33}$ Matthew's saying is a similar variant. It is assumed also that the proverb in Sir 38:15 was in general circulation and was later added to the text: אשר חוטא לפני עושהו יתגבר לפני רופא, "Whoever sins against his Maker, will end up in the doctor's hands." ${ }^{54}$ Indeed the doctor figures as someone to be avoided. This is not associated with his

50) Keener, Commentary, 168. Compare Isa 1:4-5 and 53:5. Davies/Allison, Commentary Vol. II, 103 cites Plutarch, Apophtegmata laconica 230 F: "Physicians are not among the healthy but spend their time among the sick."

51) This verse is not available in the extant Hebrew manuscripts.

52) S. Noorda, "Illness and Sin, Forgiving and Healing: The Connection of Medical Treatment and Religious Belief in Ben Sira 38:1-15," in Studies in Hellenistic Religions (ed. M.J. Vermaseren; EPRO 78; Leiden: Brill, 1979) 215-224 however discerns this cynical view of the doctor. G. Veltri, Magie und Halakha: Ansätze zu einem empirischen Wissenschaftsbegriff im spätantiken und frühmitteralterlichen Judentum (TSAJ 62; Tübingen: Mohr Siebeck, 1997) 267-268, presumes the positive influence of Hellenistic culture.

53) Hebrew text according to ms. B. A marginal note in ms. B corrects the reading to צרכך. Ms. D reads: "because (לפי) you need him." Parallel in Shemot Rabba 21:1; see also the commentary of M.Z. Segal, Sefer Ben Sira Hashalem (4 th. ed.; Jerusalem: Bialik, 1997) 245.

54) See for this verse, only extant in ms. B, P. Beentjes, "Jesus Sirach 38:1-15: Problemen rondom een symbool," Bijdr 41 (1980): 260-265 and J. Nelis, "Sir 38:15," in Von Kanaan bis Kerala (AOAT 211; ed. W.C. Delsman; Neukirchen: Neukirchner Verlag, 1982) 173-184. 
person but with the sin which man must avoid. The doctor has to intervene, when a person has sinned..$^{55}$

In that light it is not surprising that Matthew's tripartite answer links the proverb with the concept of repentance (see our discussion of part C). The doctor only appears if someone has sinned, and the only remedy is repentance. Indeed, both Matthew's Jesus and the rabbinic world aggrandize repentance. ${ }^{56}$

\subsection{The Torah as Doctor or the Teacher as Doctor}

Jesus represents a radical opinion within the early Jewish world, as he sought out the company of sinners even before they had been converted. ${ }^{57}$ This position was unusual and controversial, though not unknown. This is illustrated by a splendid anecdote:

Near where R. Zeïra ${ }^{58}$ lived, there lived some robbers. Nonetheless he was friendly to them (דהוה מקרב להו) in order to induce them to repent, but the rabbis were annoyed. When R. Zeïra's soul went to rest, the robbers said: 'Up till now we had the sunburnt man with the short legs to plead for mercy for us, and now, who will do that?' Then they felt regret in their hearts and repented. (b. Sanh. 37a)

R. Zeïra wanted to bring these brutes to the point of repentance by his behaviour, but that provoked negative reactions in his colleagues. Nonetheless the Talmud notes the (late) success of this strategy.

Likewise, Jesus saw the sinner as one who had become sick and needed the curative care of a doctor. This curative care lay in having meals and, like the friendly behaviour of R. Zeïra, was directed towards repentance. This was what started the healing process.

\footnotetext{
55) Veltri, Magie und Halakha, 269-281.

56) Abrahams, Studies, 58 shows the elevated idea of repentance to be an essential part of Pharisaic and rabbinic thought, taken to a melodramatic level: "Better is an hour of repentance and good deeds than the whole life of the world to come" ( $m$. 'Abot 4:16). According to a critical view however it is difficult for a tax-collector to repent ( $t$. B. Qam. 10:14; cf. b. B. Qam 94b). The reason for this is, that he cannot pay back the victims of his corruption and that makes reconciliation difficult.

57) Abrahams, Studies, 58; Keener, Commentary, 297.

58) Babylonian Amora (around 300 C.E.) who learned in Erets Israel. He had acquired his nickname as the result of an incident in his life.
} 
What is interesting in this connection is the designation of Jesus as doctor. The proverb calls to mind the biblical metaphor of God as physician. The rabbinic explanation linked this to the power of the Torah. Healing from sickness lay in listening to and putting into practice the words of the Torah, according to an early commentator on Exod 15:26, "for I the Lord am your healer." ${ }^{59}$ Matthew emphasised the power which went out from the teacher himself. When Jesus here takes the initiating role, he does something which is reserved for God, or the Torah, as the rabbis say. The proverb of the doctor then embodies another christological idea which probably already goes back to the historical Jesus. Jesus is even able to bring sinners to repentance, as he had done directly before this dispute with Matthew/Levi.

The proverb also throws light on another aspect of Jesus: he is immune to corruption in his contact with representatives of the Roman system. This was the answer of Jesus to the implicit criticism of the Pharisees that contact with sinners would lead to corruption. ${ }^{60}$ Holding a meal is therefore not only a strategy to bring people to repentance, but a strategy which typified the person of Jesus, according to Matthew's narrative.

\section{The Answer, Part (B): "Go and Learn"}

It is not necessary to read Matthew's use of the term go and learn as criticism, as if his opponents had not read Hosea. ${ }^{61}$ The Greek turn of phrase

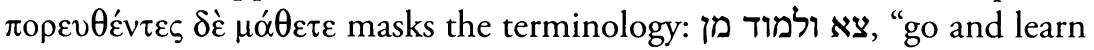

\footnotetext{
59) Mek. deR. Ishmael (ed. Horovitz/Rabin, 157-158), quoting Prov 4:22. The power of Torah study is also pivotal in the rabbinic explanation of Jer 3:22 and 17:14 ("Lord, heal me and I shall be healed") and Jer 30:17 ("I will restore health to you, and your wounds I will heal").

${ }^{60)}$ The reader would already have understood that Jesus was not susceptible to corruption in the episode concerning the temptation in the wilderness (Matt 4:1-11).

61) As Keener, Commentary, 298 proposes. According to Davies, Commentary Vol. II, 104 the citation is intended to show, that the Pharisees lacked "imagination." I can see no signs in the text to justify such conclusions. A critical undercurrent is indeed present when Matthew again cites Hos 6:6, in Matt 12:7.
} 
from this." ${ }^{2}$ This rhetorical phrase functions in rabbinic texts as a call to learn something from a specific context. ${ }^{63}$

\section{1. "I Desire Mercy and Not Sacrifice" (Hos 6:6)}

The origin of this quotation is controversial. It is identical to the version of the LXX according to Codex Alexandrinus and to Aquila. However it is more probably Matthew's own attempt at translation. ${ }^{64}$ It is well estab-

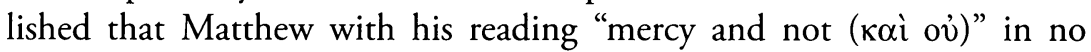
way disregards or denies the cultic ceremonial in the gospel (Matt 5:18, 23f.; 2:23-28).

The citation would be an ironic criticism of a religiosity which was not inspired by mercy. ${ }^{65}$ Finally it is thought that Hos 6:6 reads as a protest against socio-religious boundary marking and that the actions of Jesus were directed at breaking down those boundaries. ${ }^{66}$ Gundry on the other hand sees the citation as a justification of Jesus' behaviour, which also shows the way for his disciples. ${ }^{67}$ It is important to note that Hos 6:6 is also quoted in the legal dispute about plucking the ears of grain on the Sabbath (Matt 12:6). The twofold presentation of Hos 6:6 in Matthew

62) Thus Sipre Numbers 115, Lev. Rab. 1:15, Tan Wayyigra 13:9. This observation goes back to Wettstein. Gundry's remark in Matthew, 168: "The resultant stress on learning rather than doing suits Matthew's interest in discipleship, which by definition is learning" is worthy of note. Nonetheless, Matthew is sooner interested in the practice (Matt 7:21-23). M.J.J. Menken, Matthew's Bible: The Old Testament Text of the Evangelist (BETL 173; Leuven: Peeters, 2004) 227-228 underlines the typical Matthean use: “... striking that the aorist imperative mathete is found three times in Matthew, in one of these in dependence on Mark (9:13 = Mark 13:28) while the verb manthanein is not used elsewhere in the Synoptic Gospels."

63) Compare the Aramaic phrase in the famous answer by Hillel to the question, of what the essence of the Torah was (b. Šabb. 31a): "whatever you do not wish to be done to you, do not do to another. The rest is explanation. Go and learn (זיל וגמור)."

64) Menken, Matthew's Bible, 229-230 qualifies Matthew's revision as close to the Targum on Hosea 6:6 and the explanation of Rabban Yohanan ben Zakai; both read the Hebrew

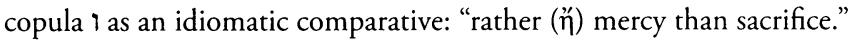

65) Davies, Commentary Vol. II, 105.

66) W. Carter, Matthew and the Margins: A Sociopolitical and Religious Reading (Maryknoll: Orbis Books, 2000) 221. Sacrifices stand for ritualism, according to Frankemölle, Matthäus, 316.

67) Gundry, Matthew, 168. 
points to the fundamental importance of this doctrine to the evangelist. ${ }^{68}$ This is a typical example of duplication, which is also detectable in rabbinic sources. ${ }^{69}$ So what justification does it concern here?

\subsection{Acts of Mercy as Atonement}

Most commentaries interpret the citation as christological. ${ }^{70}$ Matthew's use of Hos 6:6, with its emphasis on its fulfilment in Jesus Christ, would be a reaction to a teaching by Rabban Yohanan ben Zakai. In his explanation of Hos 6:6 this first-century teacher places emphasis on the reconciling power of charity as a replacement for cultic sacrifice: "We have a means of reconciliation which is like it (יש לנו כפרה אחת שהיא כמותה), and what is that? Deeds of love (גמילות חסדים)." ביםמת In Matthew, this replacement is the fulfilled mercy in Christ. But a sheer christological explanation of Matthew's quotation of Hos 6:6 ignores the legal logic of the three-pronged proverb. Firstly this lies in the rhetorical and traditional character of the phrase go and learn. Secondly within the threefold structure of the answer which Jesus provides, the citation offers a scriptural legitimation for his behaviour and indicates a legally scholastic discourse. ${ }^{72}$ That is also discernible in Matt 12:6, where Hos 6:6 is a connecting link between two Sabbath disputes, and a purely christological explanation misses the point of the aspect of legal interpretation. ${ }^{73}$ Thirdly Matthew underlines the need to maintain the law and to practise the teaching of Jesus (see e.g. Matt 7:21-23; 19:17). This teaching is summarised in the double love commandment and Matthew underlines the fact (Matt 22:40) that "On these two commandments depend all the law and the prophets."

\footnotetext{
68) For the rhetorical and legal-historical context in Matt 23, see H.J. Becker, Auf der Kathedra des Mose: Rabbinisch-theologisches Denken und antirabbinische Polemik in Mattbäus 23:1-12 (Berlin: Institut Kirche und Judentum, 1990) 169-173.

69) M. Goulder, Midrash and Lecture in Matthew (London: SPCK, 1974) 37.

70) D. Hill, "On the Use and Function of Hosea 6:6 in Matthew's Gospel," NTS 24 (1978) 107-119; L. Lybaek, "Matthew's Use of Hosea 6.6 in the Context of the Sabbath Controversies," in The Scriptures in the Gospels (ed. C.M. Tucket; BETL 131; Leuven: Peeters, 1997) 491-499. Luz, Matthäus, 45 even sees the citation as a realisation of Matt 5:17. The sick call Jesus, using the exclamation eleison (Matt 9:27; 15:22; 17:15; 20:30).

71) 'Abot. R. Nat., a 4, ed. Schechter, 11 a; b 8, ed. Schechter, 11 b.

72) Theissen, Historische Jesus, 349 interprets Jesus' actions as an extension of love for one's fellow man.

73) For a legal-historical context see Ottenheijm, "Genezen als goed doen," 351-352 and for the rhetorical function of the citation, Luz, Matthäus, 231-232.
} 
In so doing he emphasises their principal meaning for the interpretation of other commandments (cf. also Matt 7:12). Finally, Matt 23:23 refers also to the doctrine of mercy, evidently without christological connotations but in the context of prioritising the Mosaic commandments. It is also not a matter playing off interpretation of the law against Christology: both are inextricably connected to each other.

Both Matthew and Rabban Yohanan ben Zakai put old concepts into practice within a context in which the Temple had fallen away. Indeed, the theology of reconciliation through the practice of the Torah is already visible in the Second Temple period. Man is justified by carrying out commandments according to 4QMMT C, 31-32: "It will be reckoned to you as righteousness if you do what is right and good before His face, for the good of yourself and of Israel." There are few early proponents of the view that commandments are as important as offering sacrifice. This is also the case in the Community Rule of Qumran, where one is taught that prayer and

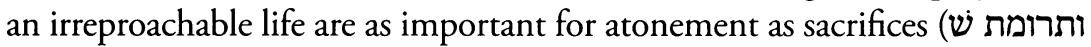
פתים למשפט כניחוח צדק ותמים דרך כנדבת מנחת רצון $1 Q S$ 9:2-7).74

Further, special emphasis is placed on good works, which have a liberating effect on those who practise them..$^{75}$ Practising mercy even protects against illnesses, a topos also present in our pericope. ${ }^{76}$ Sirach underlines the idea that keeping the commandments, practising mercy and giving alms has the same significance as bringing sacrifices. ${ }^{77}$

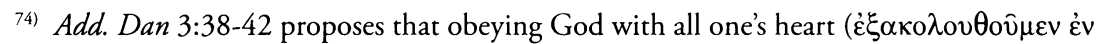

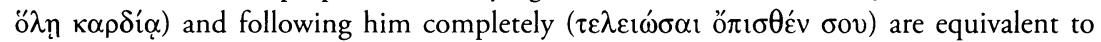
offering sacrifices.

75) E. Ottenheijm, "The Phrase 'Good Works' in Early Judaism: A Universal Code for the Jewish Law," in Empsychoi Logoi: Religious Innovations in Antiquity. Studies in Honour of Pieter Willem van der Horst (eds. A. Houtman, A. de Jong and M. Misset-van der Weg; Leiden: Brill, 2008) 485-506.

76) Whoever shows mercy is protected against illness, according to T. Ash. 2 and T. Zeb. 5:4. See for the Jewish sources of these sources J.J. Collins, "Testaments," in Jewish Writings of the Second Temple Period: Apocrypha, Pseudepigrapha, Qumran Sectarian Writings, Philo, Josephus (ed. M. Stone; CRINT 11/2; Assen/Philadelphia: Fortress Press, 1984) 342-343.

77) "Whoever heeds the law, brings many sacrifices,

whoever keeps the commandments, also brings a peace-offering,

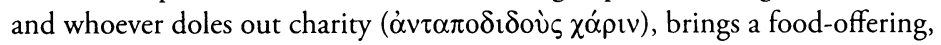

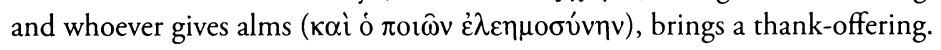

The Lord has pleasure when anger is broken off,

and breaking with unrighteousness is atonement." (Sir 35:1-5, LXX)

For the combination of alms and charity, see $m$. Pe'ah 1:1 and the commentary of the Yerushalmi ad loc. 


\subsection{Nature and Meaning of Acts of Charity}

Gemillut hesed, Acts of Charity (גומלות חסד, literally: rewarding with love), are informal actions on the level of interpersonal relations. The nature and number of these vary. ${ }^{78}$ Nonetheless we can distinguish a number of these: burying the dead, accompanying the bride, supporting the poor and orphans, visiting the sick, ransoming slaves, visiting and providing for prisoners. ${ }^{79}$

The power of these actions is widely spoken of. Notorious sinners were saved or appeared to save the community thanks to one of the earlier mentioned good works. There is the case of the story of a man with the peculiar name pentakaka, someone who was the lowest of the low, whose prayer seemed to have been effective in a time of drought. ${ }^{80}$ When later asked about it by the bemused teachers, he remembered that he had once given a woman some money and had thus enabled her to ransom her husband without having to resort to prostitution. In another story the main character was a prison warder who provided for his prisoners. This incidentally is also one of the acts of charity (b. Táanit 22a).

Such stories follow a fixed pattern: a great sinner in the past totally unselfishly carried out a good deed, and this brought him or the community salvation at a later date. This is also the case in Matthew. The altruism, coupled with a motif of ignorance, figures in the address about the end of time, when the righteous wonder when they have done a charitable deed: "Lord, when did we see thee hungry and feed thee, or thirsty and give thee drink?" (Matt 25:37-39) Acts of charity which are performed will eventually come to light, and mutatis mutandis this also applies to neglecting them. The performing of these acts is even the decisive criterion in the soteriology of Matthew.

Acts of charity cannot be formally regulated and perhaps because of this, breach an objective classification of moral reality. Hos 6:6 points out this reality, according to Matthew's account. In it he throws light on a nuance other than that shown in the explanation of Rabban Yohanan ben Zakai who puts into perspective the loss of the Temple service. But in

\footnotetext{
78) See for a(n incomplete) summary W.D. Davies and D.C. Allison, A Critical and Exegetical Commentary according to Saint Matthew: Vol. III: Commentary on Matthew XIXXXVIII (ICC; Edinburgh: Clark, 1997) 426.

79) The sequel in 'Abot R. Nat. a 4 mentions helping and cheering the bride, burying the dead, giving alms and even thrice daily prayer.

80) y. Táanit l:3 (64b); Abrahams, Studies, 60-61.
} 
both cases Hos 6:6 is based on a theology in which acts of mercy are more important than Temple service and the commandments associated with it (laws concerning sacrifice, purification, etc.). ${ }^{81}$ As noted earlier, cultic commandments like sacrifice (Matt 5:23-24), Sabbath (Matt 24:20) or prayer belts (Matt 23:5) are not discredited by these. With this re-ordering of priorities Matthew steers a course through the legal possibilities in early Judaism. ${ }^{82}$

\section{The Answer. Part (C): "I Came Not"}

The third part of Jesus' answer is the proverb (C) in vs. 13: "I came not to call the righteous, but sinners". The connection with the meal tempts commentators to take the view that Jesus would in his dealings with people reach out to grasp an eschatological reality, but this explanation is forced. ${ }^{83}$ The phrase I came is characteristic of Matthew (Matt 5:17a/17b; 9:13b; 10:34a/34b; 10:35, 20:28) but possibly goes back to the historical Jesus (cf. Luke 12:51). ${ }^{84}$ The term to call can carry the meaning of discipleship, for example when he called the disciples (Matt 4:21), although Matthew uses other concepts elsewhere. ${ }^{85}$ The proverb refers back in this case to the story of the call of Matthew/Levi; Jesus recruited his disciples directly and on the strength of his words, from among fishermen and even tax-collectors. ${ }^{86}$

The ambiguous meaning of the proverb quickly led to the need for an explanation. This might be the reason why some textual witnesses add:

\footnotetext{
81) According to version b: כפרה אחרת תחתיה, "another atonement instead of it."

82) Saldarini, Matthew's Community, 50 notes that Matthew "deemphasizes these important boundary-setting mechanisms and thus changes the nature of his community."

83) Luz, Matthäus, 45; according to Gundry, Matthew, 168 the saying refers to the called to the eschatological meal, cf. Matt 22:3-4,8-9; Keener, Commentary, 298-299; Davies, Commentary Vol. II, 101. But Matthew's version of the parable accentuates the uncertainty of the "called," as becomes clear in the judgement on the man without a wedding garment and in the proverb in Matt 22:14: "Many are called, but few are chosen."

84) Theissen, Historische Jezus, 337, 458 characterises the proverb as a summary of his preaching. Note A. Schlatter, Das Evangelium nach Matthäus ausgelegt für Bibelleser (neue, durchges. Aufl.; Stuttgart: Calwer, 1977) 310: "Der Gerechte ist es in Wirklichkeit; denn er tut, was das Gesetz ihm als Gottesdienst vorschreibt. (...) Jesus ehrt seine Gerechtigkeit eben dadurch, dass er nicht ihn, sondern die Gefallenen ruft."

85) See also Davies, Commentary Vol. II, 105-106.

86) The "Markinische Typus," according to Theissen, Historische Jezus, 198.
} 


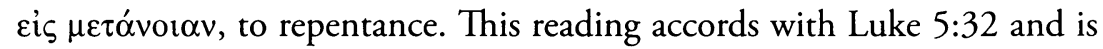
almost certainly secondary. ${ }^{87}$ Nonetheless this variant offers an authentic interpretation of the apodictic proverb. It supports the connection between Jesus and the preaching of John the Baptist (Matt 3:2, 8). Jesus moreover calls on people, to repent in the light of the dawn of the Kingdom of God (Matt 4:17/Mark 1:14-5). This interpretation is continued in Justin's explanation of the proverb:

This is what he said then: I came not to call the righteous, but sinners to repentance. The Heavenly Father would therefore rather $(\ddot{\eta})$ have the repentance of the sinner, than his punishment. ${ }^{88}$

\section{Conclusions}

The pericope does not mark a break with Judaism, although it elucidates the exceptional practice of an exceptional teacher. The question of the Pharisees can be explained from the viewpoint that Torah teachers did not associate with tax-collectors and notorious sinners. The development of the halakha on the status of the tax-collector, as well as the debate between Pharisaic factions over the suitability of disciples for Torah study indicate that this strict view was under discussion in the first century C.E. Our pericope reflects an internal Jewish debate over the question of how to deal with notorious lawbreakers, an issue relevant for the community of Matthew (Matt 18). The question addressed to Jesus is at the same time a question about the nature of his leadership. Jesus' reply makes a connection between traditional motifs. In a unique way Jesus typifies himself as the doctor and relates his appearance to the perspective of God himself. In this we can discern a christological motif that very probably goes back to the historical Jesus.

\footnotetext{
87) Note B.M. Metger, B.D. Ehrman, The Text of the New Testament: Its Transmission, Corruption and Restoration (4th ed.; NewYork/Oxford: Oxford UP, 2005) 263: "Not a few scribes supposed that something is lacking in the statement (...)."

88) Justin, Apologia l. 15,8. This commentary has a striking parallel in a tradition concerning R. Meïr (beginning of the second century C.E.). When this teacher once prayed for the punishment of thieves who were in his village, his wife Beruriah criticised him, citing Ps 104:35, that God desired the destruction of sin, not of the sinner (b. Ber. 10a/b. Ta'an. 23b).
} 
Using the citation from Hos 6:6, Matthew legitimises the meal which Jesus took with sinners as a strategy for coming into contact with them. He did not take their objective state, but their subjective possibilities as his starting-point: the sinner and the tax-collector were still in a position to experience repentance and atonement.

The Hosea citation furthermore indicates a soteriology of good works. That concept is at the core of how the law is interpreted in Matthew's gospel (Matt 12:6; Matt 23:23) and it is more specifically expanded on in the eschatological address by the Son of Man in Matt 25:31-46. This Matthean theology of good works does not replace the Mosaic law system, but develops from within the law to become a hierarchy within the commandments. In our case this logic results in a subtle balance of objectively observable categories of good and evil: there is always the potential for change for the better, and this change is connected with doing good works.

Finally, our analysis elucidates the logical connection in the three-part answer given by Jesus: Jesus is the doctor who seeks out the sick sinner in order to cure him (A). The curative method involves having a meal with the sinner so that he can be taken out of his social isolation. This strategy is linked with the priority given to acts of charity and it justifies the practice in the community of actively encouraging the sinner (Matt 18:15-17) to repent (B). The purpose of the coming of Jesus was after all to call the sinner to repentance $(\mathrm{C})$. In short, Matthew's quotation from Hos 6:6 designates eating with sinners and tax-collectors as a prophetically legitimised therapy. ${ }^{89}$

${ }^{89)}$ I would like to thank Prof. Dr. Maarten Menken, Prof. Dr. Annette Merz and Prof. Dr. Panc Beentjes, for useful suggestions. The English text was prepared by Helen Richardson. 